\title{
Between Local Power and Global Politics: Playing with Languages in the Franciscan Printing Press of Jerusalem
}

\author{
Leyla Dakhli
}

As part of an organization that placed Propaganda Fide at the centre, both in Jerusalem and in other capitals of the region such as Beirut - where the Jesuit missionaries set up their College, library and Printing house (1853) between 1847 and $1875^{1}$ - and Cairo - where the Dominicans began their intellectual missions a little later, ${ }^{2}$ the Franciscan Printing Press (FPP) of Jerusalem, founded in 1846, played a fundamental role in the mid-nineteenth century. Its work took place on different levels, all related to what Henry Laurens calls the "rediscovery of the Holy Land." 3 First, there was teaching and pedagogical support: the printing house produced and distributed school materials, textbooks and other educational tools to schools throughout the Middle East. Thus, the Franciscans entered a highly competitive race to set up educational institutions in the Arab provinces of the Ottoman Empire, while the Empire itself opened its own state institutions in line with the ethos of the Tanzimat. Secondly, they supported Roman Catholics in the Holy Land, ${ }^{4}$ notably by the publication and dissemination of guides for pilgrims and Mass programmes for local churches. Ultimately, an evolution took place regarding languages and transitions between them. The printing house progressively became a centre for translation and for distributing religious and secular material translated into Arabic, reflecting the need to place importance on this language, which

1 Chantal Verdeil, La mission jésuite du Mont-Liban et de Syrie (1830-1864) (Paris: Les Indes Savantes, 2011).

2 Dominique Avon, Les Frères prêcheurs en Orient: Les dominicains du Caire, années 1910 - années 196o (Paris: Cerf/Histoire, 2005).

3 Henry Laurens, La Question de Palestine, I: L'invention de la Terre sainte (1799-1922) (Paris: Fayard, 1999).

4 Bernard Heyberger and Chantal Verdeil, "The 'Jesuits' discourse on the Holy Land (Seventeenth to Nineteenth Centuries)," in New Faith in Ancient Lands, Western Missions in the Middle East in the Nineteenth and Early Twentieth Centuries, ed. Heleen Murre-van den Berg (Leiden: Brill, 2006), 19-42. 
had become the main vehicle of expression for Christians in the region, gradually replacing the languages of worship.

The role of the FPP was nevertheless different from the role it played at the Saint Joseph University of Beirut, for example, where it was central to the construction of the Arab Christian Nahda, ${ }^{5}$ notably in the work of Father Louis Cheikho and the Oriental school built around the university and the Oriental Library, as well as the journal Al-Mashriq. In Jerusalem, the work was of a different sort: the printing house focused less on science and intellectual studies and more on the city itself, its daily activities (in particular the increased production of stationery and the supply of materials such as visiting cards, labels and letterhead paper) and the politics that played out between the various churches and denominations on the one hand, and between those who held power on the other.

At the intersection of these different levels a certain kind of language politics played out within the Custody, visible in the works of the Tipografia (the Italian name for FPP). This chapter is based on papers kept in the archives of the Franciscan Printing Press - which now have been inventoried and organized thanks to the work of the archivist friars - as well as papers in the library of the Custody, where there were some unidentified boxes containing copies of the materials manufactured at the printing house as well as some archive pieces. ${ }^{6}$

This chapter deals with the question of citadinité, i.e., ways of inhabiting the city of Jerusalem, ${ }^{7}$ through the question of language and its uses - spoken, written, recited, displayed. I try to articulate a local approach to the more international and global dimension of language politics at work in the city. Thus, I discuss the linguistic question not a priori as a mark of identity, as a language linked to a segment of the urban population, or as contributing to a teleological reading of national identity construction (especially through the arabization of the people of Jerusalem or the rites in the Holy Land). The aim of language approach is more modest: to account for the "sound of the city" between 1847 (the date the printing house was founded) and the time of the British Mandate. This perspective is also at the heart of the strategy established by the Custody

5 Anon., "L'imprimerie catholique de Beyrouth et son œuvre en Orient," in Fascicules supplémentaires des Relations d'Orient (Brussels: Polleunis et Ceuterick imprimeurs, 1903).

6 Special thanks to Fr Serguey Loktionov and Fr Narcyz Klimas for their continued help and support. The archives will be referred to here by their Italian name, Archivo Storico della Custodia di Terra Santa (ASCTS). The inventory of part of the collection has been published: A. Maiarelli, L'Archivio storico della Custodia di Terra Santa (ASCTS) (1230-1970) (Milan: Edizioni Terra Santa, 2012), 3 vol.

7 This work was carried out within the framework of ERC Open Jerusalem, coordinated by Vincent Lemire. The concept of Citadinité is at the centre of this programme, following the works of urban historians and focusing on material archives of the city. 
in the Holy Land, i.e., that of political influence and profitable commerce as much as spiritual support, which I will try to analyse here.

It is a matter of understanding the different levels of politics at work linguistically, starting from the typographical workshop itself and then the Franciscan mission in its spiritual and temporal dimensions, in order to clarify the role of this linguistic production in the context of an international rivalry for control of the region. Paradoxically, the work of the FPP is little known, although Ami Ayalon, referring to it briefly in his great history of writing in Palestine, notes that "the Franciscans, starting as early as 1846 , ran the most active operation in this field [printing]" and mentions the considerable number of works published in Arabic at the F P P before 1900 and between 1900 and $1948 .^{8}$

\section{Learning and Teaching Languages, at the Heart of the Mission in the Holy Land}

At the turn of the twentieth century Jerusalem could be considered a classical Levantine city, where many possible definitions of cosmopolitanism were in play, ${ }^{9}$ and where the many religions generated and maintained ancient polyglossia, stemming from the languages of worship, sacred or sanctified languages, overlaid communities, successive migrations, and also of the presence of tutelary powers, linking together Church and State, or churches and states. ${ }^{10}$ In 1920, one could hear and read Arabic, Hebrew, Ladino, Syriac, Ethiopian, Greek, Armenian, and also English, German, Russian, French and Italian. Within the Custody, the lingua franca among the friars was Italian, at first. However, they learned or improved their Arabic as soon as they arrived, and some of the textbooks produced by the Press were intended to sustain the

8 Ami Ayalon, Reading Palestine. Printing and Literacy, 1900-1948 (Austin: University of Texas Press, 2004), 57.

9 On these debates: Khaled Fahmy, "For Cavafy, with love and squalor" and "Towards a Social History of Modern Alexandria" in Alexandria: Real and Imagined, ed. A. Hirst and M. Silk (Ashgate: Aldershot, 2004), 263-280 and 281-306; Ulrike Freitag, "Cosmopolitanism in the Middle East as part of global history," ZMO Programmatic Texts 4, 2010; Will Hanley. "Grieving Cosmopolitanism in Middle East Studies," History Compass 6, 2008: 1346-1367.

10 Among the many works on these questions of belonging I refer to the figure of "Tâlib Mushtâq;" see Peter Wien, "Waiting for the Superman. A New Generation of Arab Nationalists in 1930s Iraq," in The Making of the Arab Intellectual. Empire, Public Sphere and the Colonial Coordinates of Selfhood, ed. Dyala Hamzah (London - New York: Routledge, 2013), 219-220; Marie-Carmen Smyrnelis, Smyrne, la ville oubliée? 1830-1930. Mémoires d'un grand port ottoman (Paris: Autrement, 2006); Robert Ilbert, Alexandrie 1830-1930. Histoire d'une communauté citadine (Cairo:IFAO, 1996); and even to the first pages of Edward Said, Out of Place, A Memoir (New York: Vintage Books, 2000). 
brothers in this apprenticeship. In the library of the Custody we can find books annotated by clergymen, and vocabulary lists bearing the visible traces of their labour (Figure 12.1). These objects allow us to easily imagine the struggle faced by European newcomers as they put their rudimentary Arabic into action for everyday use. Vocabulary lists and conjugated verbs were copied diligently, in ink, in notebooks. These markings can tell us about the confrontation between their painstaking learning and the less rigid but more confusing language of everyday. The Italian language used in the convent was part of the domestic universe of all those who entered into religious life, something they could brandish as a sign of belonging to an order, as others did with French, Greek or Russian as the language of the mission.

On the other hand, the language of the workshop was not a given, it was a fundamental question that arose as soon as the printing house and the other

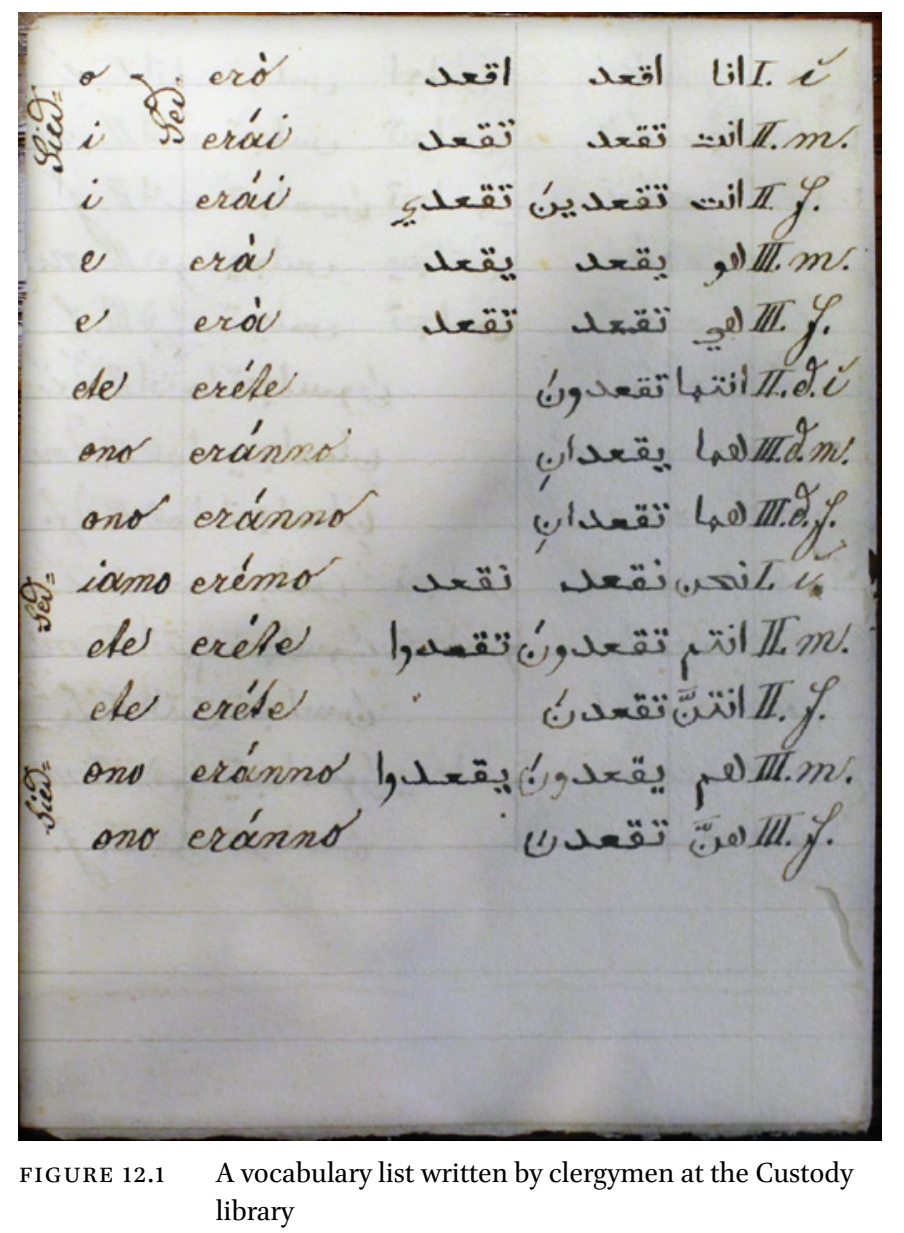


productions of the Convent were installed. ${ }^{11}$ At the end of the nineteenth century, the director of the printing house, a European Franciscan, Fr Guido, ensured that the technical operations ran smoothly and also that the workers received a Christian education: he specifically required them to go to morning Mass before work, and organized weekly spiritual conferences. These were held in Italian, or sometimes in Latin. But from the 1870s, in the interest of reaching out to the workers, the spiritual directors began carrying out this mission in Arabic. The notes taken by Fr Guido in the early 188 os show that he experienced considerable difficulty with this task because it called into question his authority over the workers, whom he considered his spiritual and temporal responsibility. On 27 August 1879 he gave a spiritual conference in Italian, which he then summarized in Arabic. ${ }^{12}$ These appearances in Arabic were always difficult, as was the recruitment of an Arabic-language corrector or the performance of various tasks in that language. This may seem surprising, but it mostly reveals the difficulty for the Catholic clergymen to constitute a loyal flock. The search for Arabic speakers, however, was largely based on practical needs. For the Franciscans of Jerusalem, the Arabic language was not presented as an end in and of itself. The Custody did not develop one of those missionary orientalist laboratories such as could be found in Rome, Paris or Beirut. ${ }^{13}$ It developed a service that was totally in line with the mission of teaching, or even evangelizing, or sometimes simply spreading the Catholic presence. The essential point was to be able to offer an efficient and high-quality service in the languages of the region and especially in Arabic, which was still underrepresented in the middle of the nineteenth century in printed material.

It was to this end that the FPP developed a specialization in linguistic tools from the very first decades of its existence, logically connected to its mission of settlement in the Holy Land and the management of pilgrimages - by definition intended for a multilingual Christian community - and its mission of teaching and charity, via a dense network of schools and orphanages, from Aleppo to Alexandria and beyond. It developed specific techniques for printing in several languages and alphabets. Bilingual textbooks were produced in large numbers and distributed to schools throughout the region. The textbooks

\footnotetext{
11 Leyla Dakhli, "The Tipografia di Terra Santa. Men at Work (1847-1930)." in Jerusalem 18401940. The Ordinary City, ed. Angelos Dalachanis and Vincent Lemire (Leiden: Brill, 2018), $326-365$.

12 ASCTs, "Brevi notizie sulla tipografia e sui direttori della medesima." Memorie della tipografia, Jerusalem, 1879 lug. 22-1899 mag. 24, p. 10 "ne ho fatto un riassunto in arabo."

13 For a critical view on this encounter between missionaries and local churches, beyond the question of languages, see Ussama Makdisi, Artillery of Heaven. American Missionaries and the Failed Conversion of the Middle East (Ithaca - New York: Cornell University Press, 2008).
} 
were also sent to the regional outposts. Thus, on 1 March 1859, 541 copies of an Italian-Arabic language textbook were sent to Beirut. ${ }^{14}$

Specialization in languages allowed the printing house, as a publishing house, to launch major projects such as the Arabic-Italian bestseller dictionary ${ }^{15}$ and the quadrilingual dictionary that the printing house team worked on throughout the year 1880. This was a French-Turkish-Italian-Arabic dictionary, to be used in the secondary school in Aleppo. On the cover the following caption was printed: Usus huius Dictionarii - pro scholis Custodiae scripti, praecipo vero pro collegio Alepensi - notitiam linguae gallicae supponit, qua deficiente vocabula aliarum linguarum inveniri non possunt. (i.e., "The use of this dictionary, intended for the schools of the Custody, such as the secondary school of Aleppo principally, assumes the readers' proficiency in French, so that they can to cope with the vocabulary that may be missing in the other languages"). This sentence, written in yet another language (Latin, i.e., the "universal" language of the Catholic Church) is appended as a kind of user instruction for the reader. It seems to imply an "inequality of languages" and the decision to opt for a single reference language - French - to organize the others and create a hierarchy between them.

This point can also be understood by reading the notebooks of the director of the Tipografia, and the notes taken during the implementation of the project. The difficulty for the dictionary lay in the fact that at that time there was no scholar at the Convent capable of dealing with each of these four languages and the flow between them. It was therefore necessary to ease the paths from one language to another by establishing a reference language, so that a three-person system for corrections was put in place: "Da qualche tempo si sta stampando un dizionarietto in 4 lingue, e le correzioni si fanno dal P. Pino, dal P. Leone, e dal P. Vincenzo. Siccome è difficile combinarsi nelle 4 lingue, è stato stabilito che si tirino 3 stamponi, e che tutti tre i correttori si radunino insieme per consultarsi e far cosi d'accordo la prima correzzione."16 The use of French as a reference language can further be explained by the fact that Aleppo was already a territory where many Catholic missions were present at that time,

\footnotetext{
14 ASCTS, "Registro dei libri spediti. C," 1857 giu. 22-1876.

15 Somehow the counterpart of Father Abougit's famous Arabic-French grammar manual and of Father Cuche's Arabic-French dictionary, both printed at the Imprimerie orientale in Beirut in the late 1850 s.

16 "For some time a dictionary in four languages was printed, with corrections made by Father Pino, Father Leone and Father Vincenzo. Since it was difficult to manage with four languages, it was decided that three sets of proofs would be printed, and that the three correctors would meet to consult and do the first correction together." ASCTs, "Brevi notizie sulla tipografia e sui direttori della medesima." Memorie della tipografia, Jerusalem, 1879 lug. 22-1899 mag. 24, 21 November 1879, p. 18.
} 
mostly French-speaking (such as the Lazarists and Capuchins). This trilingual (or even quadrilingual, if we add the language of the Empire) composition of the Catholics of Aleppo was observed by Henry Bretonneau, who in 1847 recorded these figures regarding the expansion of Catholicism: "In Aleppo there are four churches or chapels of the Latin rite. There are eight missionaries: two Lazarists, two Capuchins, three Fathers of the Holy Land and one Carmelite. The main church is that of the fathers of the Holy Land, also known as the guardians of the Holy Sepulchre; it is strictly the parish church of the Latins. They preach in Arabic and Italian, and sometimes in French."17

The specific and official goal of the clergymen, which was constantly reiterated, and corresponded to the mission of growing and spreading the Catholic faith according to the idea of the universal Church, was to circulate languages and translations. The printing house is a place to observe the techniques used for this circulation; the printers followed a colonial vision that manifested itself in appropriations of languages and gestures, and which viewed its presence as an unequally shared labour of "exchange" and "reciprocity." In doing this, translation can be seen as one of the strongest and most subtle weapons of conquest. ${ }^{18}$

The Printing House, as a company that was open to anyone in the city, had first and foremost the task of adapting to the polyglossia that surrounded it. It printed in multiple languages, and the material it purchased, built and collected had to be adaptable to orders, and to moving from one language to another. Thus, the types used by the Printing house were ordered project by project, ${ }^{19}$ adjusted with time, and modified in such a way that the writing could meet the requirements of the authors as well as the readers. The account books for the first three decades of business show how the printing of Arabic type created specific problems and required regular adjustments. The search for a competent

17 Henry Bretonneau, La Religion triomphante, par les plus grands hommes, dans toutes les carrières, dans tous les pays et dans tous les siècles (Paris: Librairie de Sagnier et Bray éditeurs, 1847), 718.

18 Shaden M. Tageldin, Disarming Words. Empire and the Seductions of Translation in Egypt (Stanford: University of California Press, 2011); Samah Selim, "Pharaoh's Revenge: Translation, Literary History and Colonial Ambivalence," in Hamzah, The Making of the Arab Intellectual, 20-39.

19 Particularly at the Catholic Press of Beirut, Cf. the order presented in "1863-1947. Commerciali (selezione). Archivio morto," Ascts, Stamperia di Terra Santa (sTs), Jerusalem. 
proofreader of Arabic texts was a source of great worry for the directors of the Tipografia in the early years. They also had to find a skilled person to modify the Arabic types on the machines, make necessary adjustments, order the right drop caps. This expert technician was often "imported" from Mount Lebanon, because he had to be both an Arab-speaker and a Catholic. Thus, the name "Simon Hallac" appeared in pencil in the registers: Simon Hallac aggiustò le matrici dell'Egiziano arabo corpo 14 (Simon Hallac fixed the masters for the Egyptian Arabic font 14), and as for corrections in Hebrew - for 1895, we find that "Levi Nahum aggiustò le matrici del'Ebreo" (Levi Nahum fixed the masters for the Hebrew) - they continuously worked with this kind of local workforce. ${ }^{20}$

Reading the list of the printing jobs conscientiously recorded by the workshop directors, citing the work, the customer and the workers in charge, one can get an idea of the diversity of texts and languages, but also of the manifestations of these languages in various places of the city. On the one hand the Franciscans printed catechisms, including 1500 copies of the famous 1847 catechism in Arabic, which was said to be the first printed book in Arabic in Palestine, and books on the history of the Crusades, on the other hand they also created 200 copies of letterhead paper for the Austrian consulate, probably in German with an Arabic or French translation. ${ }^{21}$

At the beginning of the twentieth century we can see how the printing house was transforming and adapting. A random sample of names culled from the payment books includes the Jerusalem Hotel, Governo (Government), Grand New Hotel, La signora Maroun (Mrs Maroun), Banco ottoman (The Ottoman Bank), le Consulat de France (The French Consulate), Bisciara di Betlemme (Bisciara of Bethlehem), Hallac per ligature (Hallac for the bindings), Suore Giuseppine del Pensionnato (Sister Giuseppine from the Pensionate), Ospedale francese (French Hospital). ${ }^{22}$ In the midst of World War I the market seems to have shrunk to only a few clients, but apparently the friars did manage to get supplies of paper. Indeed, it would seem that they largely became stationery suppliers: visiting cards, labels, printed envelopes, letterhead paper, and also programmes for Mass and catechisms. The customers were less diverse and more specific, often linked to the Patriarchate, a number of religious orders, schools, and a few faithful - and financially stable - customers such as Banco di Roma and Crédit Lyonnais. ${ }^{23}$

\footnotetext{
20 Ascts, Miscellanea Stampi della tipografia, 1890 gen. 2-1909 gen. 11.

21 List of works made at the printing house, "Stampe giornaliere dal 1882-1895," archive boxes kept at the Biblioteca Generalis custodiae terrae sanctae, Jerusalem. 
These are the customers that we can also find after the war, some so well known that they are simply referred to as avvocato turco (Turkish lawyer) or L'Ebreo dei Fiori (the Hebrew of flowers). The books are organized "by customer": Tribunale del Patriarcato (Tribunal of the Patriarcate), Salesiani di Gerusalemme (Salesians of Jerusalem), Scuola Inglese Cattolica di Betlemme (Catholic English school of Bethlehem), Mons. Fellinger (Bishop Fellinger), Suore Carmelite (Carmelite Sisters), Padri gesuiti (Jesuit Fathers), Fast, D. Dunkel, Consulate of France, Consulate of Spain, ospedale italiano (Italian Hospital), Department of Antiquities. ${ }^{24}$

It is this growth in production that ensured that the Custody's printing house became a kind of central printing house for the city, both a service provider for its many private clients and official printer for the Ottoman Empire, and then also for the British Mandate. At the end of the First World War, thanks to the technical advances made in the Franciscan workshop and its capacity to deal with orders, the Custody produced all of the official material for the British government: posters, ads for public squares, trilingual or quadrilingual war reports, ${ }^{25}$ and even order forms for police boots (Figure 12.2). At the same time, they were printing railway tickets, receipt books for banks, luggage labels, letterhead paper for hotels, shops, post offices and schools.

The FPP's distinctive capacity to move between languages explains why it would take on the role of national printing house ${ }^{26}$ at the time of the British arrival. In this it differed from other printers, who remained very much oriented towards the particular demands of their communities (Armenian or Greek printing presses, for example). The work carried out for the Mandate (Jerusalem Head Quarters) was the subject of a separate book from 1918, where could be found laisser-passers, official declarations in four languages ("inglese, arabo, francese, ebreo"), labels, administrative stationery, forms, posters, notices, musical programs, blank passports, prisoner's cards, telegram forms, post office registers, the Daily Hospital report, the Register of Wanted Persons, gendarmerie papers, building permits, conversion tables (for exchange rates), passes for entering the City Walls, commodity prices, contract forms, medical prescriptions, papers for the Jerusalem School of Music, a profusion of paper pronouncing political power in the languages of the city. They formed a very large part of the orders, later grouped under the name "Central Stores," in which large sums of money figure, among the only ones to be settled monthly.

24 ASCTS, Miscellanea Tipografia, 1925 apr. 20-1930 nov. 17.

25 ASCTS, "Bollettini di Guerra" (1918), Proclami e ordinanze del governo premandatario, in Carteggio, Archivio Morto1/1918-1919.

26 Some elements in the account books suggest that the Franciscans also performed this type of task for the Ottoman government prior to this (1873, in 1857 giu.15-1879 dic.31, "Giornale de' lavori. B." “Giornale delle prestazioni della tipografia," ASCTs, sTs, Jerusalem). 


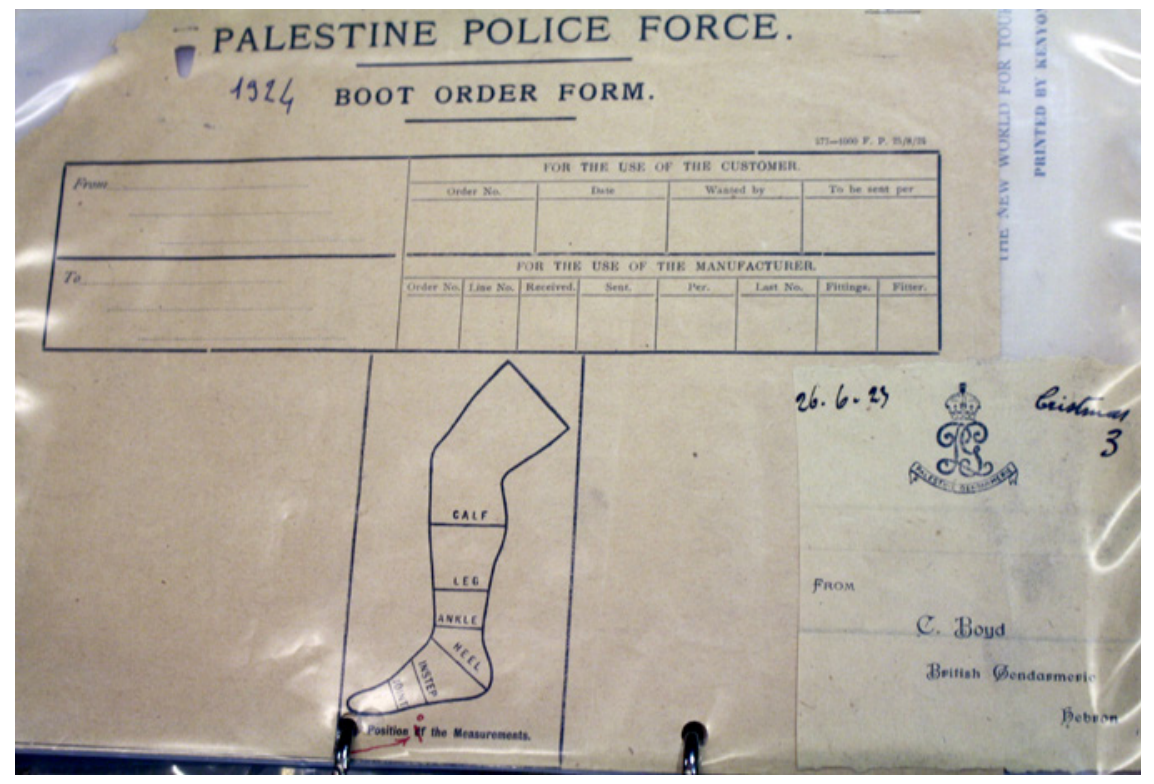

FIGURE 12.2 An order form for police boots issued by the Custody library

In addition to this particular customer there were other major clients such as Banco di Roma, Crédit Lyonnais and institutions such as the French Hospital or the Régie des Tabacs, as well as the consulates, which appear in the account books from March 1920.

The archives of the printing house beyond the Custody thus allow us to observe how the administration of the Mandate established itself, creating its place in the city, and to understand the Mandate's organization on a city-wide scale. The British adapted themselves to the already ancient customs that governed public life, that of the business of men and gods in Jerusalem, that of transitions between worlds that were at once diverse and places of ordered coexistence. When reading printed material from the Tipografia, we can perceive the diversity of both the languages in use and their corresponding registers. Visiting cards indicated a merchant's trade in the languages of the customers, real and desired. They were ordered in English in the hope of attracting "international" clientele, and printed in several languages to highlight the merchant's Dragoman talents. ${ }^{27}$ Banking forms were also bilingual, or even trilingual, for use by the country's inhabitants. Consulates printed holiday menus in their own language, sometimes translated into English, French or, more rarely,

27 Maria-Chiara Rioli, "Introducing Jerusalem: Visiting Cards and Urban Identities at the Turn of the 2oth Century," in Jerusalem 1840-1940 The Ordinary City, edited by Angelos Dalachanis and Vincent Lemire (Leiden: Brill, 2018). 
into Arabic. Sounds, noises, and even the clamour of the city are transmitted through these papers, murmuring with urban life in all its diversity. They reveal the customs of various social circles.

Continuous translation can also be seen in the exchanges of/between currencies, which also seem to have been a natural part of conducting business in the city of Jerusalem. One could pay in francs, centimes, pounds, or old piastres, and the exchange rates fluctuated as much as the currency in use. Even before printing, the raw materials and tools used for the task, such as the printing machines, travelled routes that linked these urban papers with other geographic zones: the machines and the early types came from Vienna, Mainz or Leipzig, the beech tables for the workshop, binding yarn, and the linseed oil used as siccative for the vegetable inks, from Venice. The colours were ordered in Turkey, some paper - notably carta fiorita - in Lyon, other types - paper for visiting cards for example - in Paris. After printing, books and papers circulated far beyond urban boundaries to supply warehouses and secondary schools in Alexandria, Mansoura, Ismailia, Port Said, Beirut, Syria, Cairo, Nazareth and even Iraq. In these ways, the printing house was indeed a hub.

\section{Languages, an Entry into the Global Political Game}

The FPP's work with and on languages was not only practical and commercial, from the outset it was also political. First, it assisted the mission, and seriously applied itself to making the Catholic message universal. In the typographic workshop and in the printing house, the languages that circulated had to meet the twofold injunction of work and spiritual elevation.

The emphasis placed on being and remaining the first Arabic-language printing house can be seen as a desire on the part of the FPP to distinguish itself from other communities, who were oriented towards their own language of worship or that of their patrons. In the 1920 s this issue was no longer as fundamental, as printing houses had expanded and did not hold the same power. They soon abandoned the role of an Arabic-language printing house, and were gradually replaced by other service providers in this field, more specialized and more integrated with the emerging market of Arabic publishing. From 1908 onward Arabic printing developed in the region, in Palestine, and Jerusalem. Newspapers and magazines flourished and Arabic authors could print their books for a good price in Cairo, Beirut or Baghdad. ${ }^{28}$ Jerusalem

28 See, among many others, Leyla Dakhli, Une génération d'intellectuels arabes. Syrie-Liban 1908-1940 (Paris: Karthala, 2009); Orit Bashkin, The Other Iraq. Pluralism and Culture in Hashemite Iraq (Stanford: Stanford University Press, 2008). 
did not escape the printing boom that followed the revolution of 1908 , and newspapers, printing presses, and even training for printing work flourished (notably at the German orphanage, Dār al-Aytam ${ }^{29}$ ). Alongside small everyday papers, dictionaries became a particularly sought-after product from the Franciscan Printing Press. We can see that the Levantine diaspora community placed orders for dictionaries or glossaries to help them live in the countries where they had settled. Thus, a Lebanese living in Chicago would order an English-Arabic vocabulary book, another in Brooklyn ordered an English textbook in Arabic, and others who were not necessarily looking for linguistic tools but a way of transmitting some of their familiar world into the other language placed orders as well. ${ }^{30}$

In the same way that the production of visiting cards was a means for the Custody to enter into the circulation of political writing in the city, the printing and translating of dictionaries was a political space that had gone unnoticed until then. In the 1920s-1930s it was notably the Custody's specialization in moving between Arabic and Italian that would gradually open up new markets for it, linked to Italian colonial expansion and to fascist politics in the East. Thus, we can see the orders for Arabic-Italian dictionaries appearing and then increasing for the Italian community in Egypt, then in Tripolitania.

In 1922 a letter from the Apostolic Vicar of Tripolitania to the Custos refers to a whole strategy of "publicity" to promote the dictionary with schools and administrations in Libya: se lei vuole ne mandi qua un centinaio di copie: ne faremo esporre dai librai. Questi, se si lascerà loro un guadagno discreto, certo faranno il tutto per venderlo, ed una volta conosciuto dal pubblico certo continuerà a vendersi bene (i.e., "If you would like, send a hundred copies here: we will have them displayed in book stores. If the stores are given some profit, they will certainly do everything they can to sell it, and once the public is aware of it, it should continue to sell strongly.") He gave advice on the distribution of the Custody's linguistic production, at a time when the Italian government needed a set of tools to translate from Arabic to Italian and, as pointed out in the same letter, also needed to develop linguistic tools to translate from Italian to Arabic. He encouraged the friars of Jerusalem to get to work: a market was opening up, and they needed to be part of it. ${ }^{31}$

This policy seems to have been followed by an increase in orders for books and dictionaries from Tripolitania, particularly in the 1930s. In 1937, thanks came in the form of a letter from the Ministry of Foreign Affairs of fascist Italy.

29 Ayalon, Reading, 59.

3о ASCTS, 1923 set. 7-1932 lug. 21, "Registro delle spedizioni dell'introito attivo."

31 ASCTS, 1863-1943, "Corrispondenza (selezione). Archivio morto." 
The Printing house had donated books to a certain number of institutions, following advice from the Apostolic Vicar of Tripolitania as early as 1922. We can hypothesize that this was a new Arabic-Italian dictionary, a project of 1935 that can be found in the archives, and whose purpose was to be "eminently practical." This new edition was intended to summarize basic knowledge, but also "eliminate all the verbal and nominal forms which are too rarely found in the ordinary style of both ancient and modern authors; to give greater importance to scientific and technological terms, to indicate the meanings of the terms in Arabic in various regions such as Egypt, Syria, Tripolitania and Algeria, not to exclude frequently used vulgar words or words that foreigners will frequently find in newspapers and periodicals." The goal was to remove language from a purely academic realm, in order to give it a practical dimension. The dictionary was specifically adapted to the areas in which Italian communities with colonial aspirations could be found. These ambitions were made quite explicit in article 10 of the proposal: "Italy needs this new Arabic-Italian dictionary for its colonies and resident connazionali in Egypt and other Muslim countries."

My point here is not to mention a shameful political collusion, but to see how the opportunity for linguistic competence combined with the fascist Italian colonial vision - which was centred on the support for missions and scholastic textbooks, as well as on learning Italian - would allow for a synergy between these two institutions. The example put in place in France via the work of the Écoles d'Orient (1865), vis-à-vis the Jesuit and Lazarist missions in nearby Syria, showed, from the nineteenth century, how cultural and intellectual policies based on Christian - Catholic - missions could be a means of establishing a strong political influence. It should be noted that the Franciscan Printing Press/F Pp became more "Italian" under Mandatory Palestine. Its most loyal customers, besides the Mandate government, included leading Italian institutions such as the Banco di Roma, where the Custody also kept its money. By printing posters and visiting cards in Italian the FPP helped to make Italian a language that circulated inside the city of Jerusalem. As Liora Halperin has shown, making languages visible in public spaces was a strategic move for Mandatory Palestine. ${ }^{32}$

From 1922 onward Italianization was linked with fascist politics, enabling the printing house to develop a whole section of its commercial activity around translations between Italian and Arabic. It is significant to note the role played by fascist politics in the Custody, which was considered a national symbol in charge of spreading Italian in the Holy Land, and the values of an

32 Liora R. Halperin, Babel in Zion: Jews, Nationalism, and Language Diversity in Palestine, 1920-1948 (Yale: Yale University Press, 2015). 
Italy in which Saint Francis was considered the national saint par excellence. ${ }^{33}$ Thus, the range of work produced by the FPP played a role in the educational propaganda developed in particular by the Minister of Education Giovanni Gentile, making the Istituto per la Propaganda della Cultura italiana a legal persona from November 1921. Moreover, it became a key element, in the Arabic-speaking territories, of the Lateran Treaty between Mussolini and the Roman Catholic Church signed in 1929. ${ }^{34}$

\section{$4 \quad$ Conclusion}

At the end of this exploration by languages of one of the major cultural institutions of Jerusalem at the turn of the twentieth century, we can understand that writing and printing in this city occurred in the context of multiple complex politics. From the outset, the installation of the Franciscan Printing Press supported the Vatican's political and religious ambitions during the reconquest of the Holy Land. Its development in one of the major urban centres of the Empire's Arab territory allowed it to create a bridge between the languages of the city and the region, by becoming an efficient multilingual printing house. Thus, from the time of the British Mandate, it was the national printing house, a place where the voices behind the policies were created, and next published in the streets of the city in multiple languages. Finally, it was as a Franciscan convent, a micro-world where Italian was the language spoken and the unofficial embassy of the Vatican, that the Press took over Italian politics in Arabic-speaking territory, politics that exempted it from the local demands of the British Mandate in Palestine so that it could engage in what was at that time a very offensive Italian imperialism.

A linguistic reading makes it possible to pinpoint the level of engagement that was held by this institution. It did not just serve as a mirror of the languages spoken, written and printed in the city, but displayed the polyglossia specific to the city of Jerusalem. As a host city for the pilgrims of the world, we can see that considerable efforts were made towards them, particularly from the 1920s onward. Beyond its spiritual vocation the Franciscan Printing Press played a key role in welcoming this particular kind of tourist. It published and printed all the papers they needed: guides, postcards, tickets to enter the city, luggage labels, forms for hotels, letterhead paper for writing down their

Tommaso Caliò and Roberto Rusconi (eds), San Francesco d'Italia. Santità e Identità nazionale (Rome: Ed. Viella, 2011). See particularly T. Caliò, "Il ritorno di San Francesco: il culto francescano nell'Italia fascista," $45^{-65}$.

Lucia Ceci, L'interesse superiore: Il Vaticano e l'Italia di Mussolini (Rome-Bari: Laterza 2013). 
thoughts, even the checks they endorsed. It also provided their guides and translators with visiting cards to aid their exposure and reputation. In this, too, the FPP followed the city as it transformed into a space where holy places were commodified, another form of politics by language.

Until the end of the Second World War the F PP remained a window for local life, where people came to order the printed material that would mark important urban moments (marriages, graduations, celebrations, funerals), or items needed for everyday professional life (labels, transport tickets, business cards, posters). Thus, the papers that were printed at the Convent of the Custody connected not only the wide world, but also urban micro-localities. At the heart of this integration is language politics, in its most concrete sense.

\section{Bibliography}

\section{Archives}

ASCTS: Archivo Storico della Custodia di Terra Santa (ASCTS). The inventory of part of the collection has been published: A. Maiarelli, L'Archivio storico della Custodia di Terra Santa (ASCTS) (1230-1970). Milan: Edizioni Terra Santa, 2012.

\section{Literature}

Anon. "Limprimerie catholique de Beyrouth et son œuvre en Orient." in Fascicules supplémentaires des Relations d'Orient. Brussels: Polleunis et Ceuterick imprimeurs, 1903. Avon, Dominique. Les Frères prêcheurs en Orient: Les dominicains du Caire, années 1910 - années 196o. Paris: Cerf/Histoire, 2005.

Ayalon, Ami. Reading Palestine. Printing and Literacy, 1900-1948. Austin: University of Texas Press, 2004.

Bashkin Orit. The Other Iraq. Pluralism and Culture in Hashemite Iraq Stanford: Stanford University Press, 2008.

Bretonneau, Henry. La Religion triomphante, par les plus grands hommes, dans toutes les carrières, dans tous les pays et dans tous les siècles. Paris: Librairie de Sagnier et Bray éditeurs, 1847 .

Caliò, Tommaso and Roberto Rusconi, eds. San Francesco d'Italia. Santità e Identità nazionale. Rome: Ed. Viella, 2011.

Caliò, Tommaso. "Il ritorno di San Francesco: il culto francescano nell'Italia fascista." In Caliò and Rusconi, San Francesco d'Italia, 45-65.

Ceci, Lucia. Linteresse superiore. Il Vaticano e l'Italia di Mussolini. Rome-Bari: Laterza 2013. Dakhli, Leyla. Une génération dintellectuels arabes. Syrie-Liban 1908-1940. Paris: Karthala, 2009.

Dakhli, Leyla. "The Tipografia di Terra Santa. Men at Work. 1847-1930)." In Dalachanis and Lemire, Jerusalem 1840-1940. 
Dalachanis, Angelos, and Vincent Lemire, eds. Jerusalem 1840-1940. The Ordinary City. Open Jerusalem vol. 1, Leiden: Brill, 2018.

Fahmy, Khaled. "For Cavafy, with love and squalor" and "Towards a Social History of Modern Alexandria." In Alexandria: Real and Imagined, edited by A. Hirst and M. Silk. Ashgate: Aldershot, 2004.

Freitag, Ulrike. "Cosmopolitanism in the Middle East as part of global history." ZMO Programmatic Texts 4 (2010).

Halperin, Liora R. Babel in Zion:Jews, Nationalism, and Language Diversity in Palestine, 1920-1948. Yale: Yale University Press, 2015.

Hamzah, Dyala, ed. The Making of the Arab Intellectual. Empire, Public Sphere and the Colonial Coordinates of Selfhood. London - New York: Routledge, 2013.

Hanley, Will. "Grieving Cosmopolitanism in Middle East Studies." History Compass 6 (2008): 1346-1367.

Heyberger, Bernard, and Chantal Verdeil. "The 'Jesuits' discourse on the Holy Land (17th-19th century)." In New Faith in Ancient Lands, Western Missions in the Middle East in the Nineteenth and Early Twentieth Centuries, edited by Heleen Murre-van den Berg. Leiden: Brill, 2006, 19-42.

Ilbert, Robert. Alexandrie 1830-1930. Histoire d'une communauté citadine. Cairo: IFAO, 1996.

Laurens, Henry. La Question de Palestine, I: Linvention de la Terre sainte (1799-1922). Paris: Fayard, 1999.

Maiarelli, A. L'Archivio storico della Custodia di Terra Santa (ASCTS) (1230-1970). Milan: Edizioni Terra Santa, 2012, 3 vol.

Makdisi, Ussama. Artillery of Heaven. American Missionaries and the Failed Conversion of the Middle East. Ithaca - New York: Cornell University Press, 2008.

Rioli, Maria-Chiara. "Introducing Jerusalem: Visiting Cards and Urban Identities at the Turn of the 2oth Century." In Dalachanis and Lemire, Jerusalem 1840-1940.

Said, Edward. Out of Place, A Memoir. New York: Vintage Books, 2000.

Selim, Samah. "Pharaoh's Revenge: Translation, Literary History and Colonial Ambivalence." In Hamzah, The Making of the Arab Intellectual, 20-39.

Smyrnelis, Marie-Carmen. Smyrne, la ville oubliée? 1830-1930. Mémoires d'un grand port ottoman. Paris: Autrement, 2006.

Tageldin, Shaden M. Disarming Words. Empire and the Seductions of Translation in Egypt. Stanford: University of California Press, 2011.

Verdeil, Chantal. La mission jésuite du Mont-Liban et de Syrie (1830-1864). Paris: Les Indes Savantes, 2011.

Wien, Peter. "Waiting for the Superman. A New Generation of Arab Nationalists in 1930s Iraq." In Hamzah, The Making of the Arab Intellectual, 219-220. 